\title{
Information Systems Strategic Planning for a Naval Hospital
}

\author{
Hery Harjono Muljo and Bens Pardamean \\ Bina Nusantara University \\ Jl. Kebon Jeruk Raya 27, Jakarta 11530, Indonesia \\ bpardamean@binus . edu
}

\begin{abstract}
This article discusses the Information System (IS) strategic planning for a naval hospital in Indonesia. Its purpose is to improve competitive advantage among hospitals through the addition of new services and products that would lead to improvements in the current patient services. The merging of Hospital Information System (HIS), Radiology Information System (RIS), and Laboratory Information System (LIS) into a single network with a concept of telemedicine is the main topic of this article. The hospital's website is also developed with medical tourism in mind, which attracts more patients, generating more revenue for the hospital.
\end{abstract}

Keywords: strategic planning, hospital information systems, telemedicine, medical tourism.

\section{Introduction}

For a company that is planning to upgrade and improve its IS/IT infrastructure, Henderson and Sifonis [1] states it should perform an Information System Strategic Planning (ISSP). The IS Strategic Planning is a useful management tool for identifying the main objective, focus, and work needed for the upgrade [2].

ISSP could also be used as a reference by any organization in designing its IS to perform current business strategics [3] as well as creating new business strategy [4] and IT architectural policy [5]. A well-designed strategy would lead to a competitive advantage [6] while a controlled strategy, which is a critical component in the design, would satisfy both the customer needs and the investor demands [7].

A naval hospital in Indonesia handles not only patients from the Navy but also from the general population that contributes more than 350,000 patients per annum, all of whom are covered by government insurance. The hospital itself has had an IS in place, maintaining the effectiveness and efficiency of day-to-day operations. However, the current system is not equipped for improving service levels or gaining more revenue. Upgrading the system to include these practices place the hospital on par with other competitors that have identified these potentials.

The research question that the author attempts to answer is how would the IS strategic planning be able to perform the following: support the hospital's business 
strategy, provide a competitive edge, improve current services, and eventually, become the backbone of the hospital's day-to-day operations?

The objectives of the research are to develop an IS strategic planning by analyzing the internal and external side of the hospital's business and the Information Technology (IT) infrastructure, and defining the IT/IS management strategy. The benefit that the hospital could gain from the development is having IT/IS strategies with competitive advantages among the competitors, supporting the hospital's management during the implementation of the IT/IS strategies, and creating new services that would strengthen the hospital as a whole.

\section{Methodology}

The development of the ISSP refers to the IS/IT strategy development model by Ward and Peppard [8] that consists of five stages. The first stage is preparation and data collection. The preparation sub-stage consists of defining the objectives, limitations, and the problem statement. The second stage is analyzing both the internal and external side of the business environment as well as both the internal and external side of the IT/IS infrastructure.

The tools for analyzing the hospital's external business environment were PEST (Politic, Economic, Social, and Technology), Porter's Five Forces, and Boston Consulting Group (BCG). As for the internal business environment, Value Chain was used to identify the hospital's strengths and weaknesses. Once all the opportunities, threats, strengths, and weaknesses were identified, a SWOT (Strengths, Weaknesses, Opportunities, Threats) analysis was performed to identify the hospital's "position" to achieve the goals. The next step was to find the Critical Success Factors (CFS) of the hospital to find necessary elements required by the hospital for achieving the goals. The third step of the analysis was performing a Gap analysis. The fourth was identifying the business IS strategy, IS/IT management strategy, and the IT strategy. The last stage was planning the IT/IS implementation strategy that would be the blueprint for the hospital.

In this study, a qualitative descriptive analysis approach was utilized for describing the actual hospital condition/environment, identifying the problems, collecting data, analyzing data and situation, as well as finding the answers to the research questions in IS/IT strategic planning form.

The study used surveys, observations, and interviews as primary sources for data analysis. The naval hospital in central Jakarta and two other hospitals were selected as primary data sources. Secondary sources were also collected, such as the population data, inflation rate, gross domestic incomes, and gross domestic expenditures from the Badan Pusat Statistik (Central Bureau of Statistics) website.

\section{Result and Discussions}

\subsection{External Business Environment Analysis}

This analysis was used to identify both the external factors related to the organization and the organization's competitive advantages against the competitor. The analytical tools were PEST, Porter's Five Forces, and BCG. 


\section{PEST (Politic, Economic, Social, and Technology) Analysis}

PEST is a useful tool for summarizing the external factors of a business. PEST prepares a business for handling external factors such as politic, economic, social, and technology. PEST factors tests predictive models for current and future scenarios [9]. PEST analysis would also be used to test the current practice and develop a new framework [10].

Politic. Indonesian Law No. 4 of 2009 Section 6 states that the hospital financing for the poor will incur additional costs for the hospital. Section 7 of the same law states that a hospital has to be established at a geographically strategic location with sufficient treatments, services, and logistics.

Economy. High inflation rate and crude oil prices (more than a $\$ 100 /$ barrel in 2012) resulted in sharp increase in drug prices and medical equipment. These conditions place the hospital at an unfavourable disadvantage.

Social. A dense population around the hospital, an increase in revenue and welfare, and various lifestyles are affecting the public health issues of the population.

Technology. Rapid growth in technology and technological literacy population has forced the naval hospital to periodically update its technological infrastructure as often as possible. Competitors that frequently update their technology could be a threat for the naval hospital's management.

\section{Porter's Five Forces}

1. Rivalry among Existing Competitors

There are four regular hospitals within the naval hospital area's geographical scope that can be considered as competitors: PELNI Hospital, PK St. Carolus Hospital, PGI Cikini Hospital, and Jakarta Hospital. These competitors are experienced and constantly improving their services, upgrading their medical equipments, renovating their faciities, and upgrading their IS.

2. Threat of New Parties

Sahid Sahirman Memorial Hospital (SSMH) is a new party to watch in the healthcare business competition. SSMH is equipped with modern technology, excellent services, big investment support, and a state-of-the-art IT/IS infrastructure.

3. Threat of Products or Services Substitution

Healthcare products and services substitution such as small local clinics, accupunture clinics, reflexology clinic must also be considered. It is highly likely that patients at one point, will opt to try alternative treatments for their illnesses due to several reasons, such as healthcare cost and treatment effectiveness.

4. Bargaining Power of Buyer

The main customers of the naval hospital are navy officers and the general population. The naval hospital has a strong bargaining power because of the requirement that navy officers check-in to this hospital when they are on duty. The naval hospital also offers a hyperbaric therapy that not many hospitals offer.

5. Bargaining Power of Supplier

The large number of suppliers that exist in the healthcare industry is also a big advantage for the naval hospital because they do not have to rely solely on one party 
for its hospital supplies. Thus, the hospital is able to negotiate its payment to the suppliers; the negotiation period can last between one to three months.

\section{Boston Consulting Group (BCG)}

BCG Matrix is a trusted and effective technique in product market decisions [11]. The matrix is also used to formulate concept-based restructuring of portfolio analysis and is useful for strategic decision making [12].

According to the BCG Matrix as shown in Figure 1, "outpatient" and "radiology" are both in the "Question Marks" category, which means that both have a low market share but a high market growth. For "inpatient", "laboratory", and "Hyperbaric" are in the "Dogs" category due to their slow market growth and low market share. "Surgical procedure" falls under the "cash cow" category due to its low market growth but high market share. The naval hospital could support all other services through the high profit and high cash generated from the "surgical procedure" service. With low market growth and no recurring investment needed, the naval hospital could keep its profit high. All the cash surplus from the "surgical procedure" service can be used to transform the "Question Marks" category to a "Share Leader" category. It can also be used to subsidize the "Dogs" category, cover the administration fees, fund research and development, as well as cover its debt.

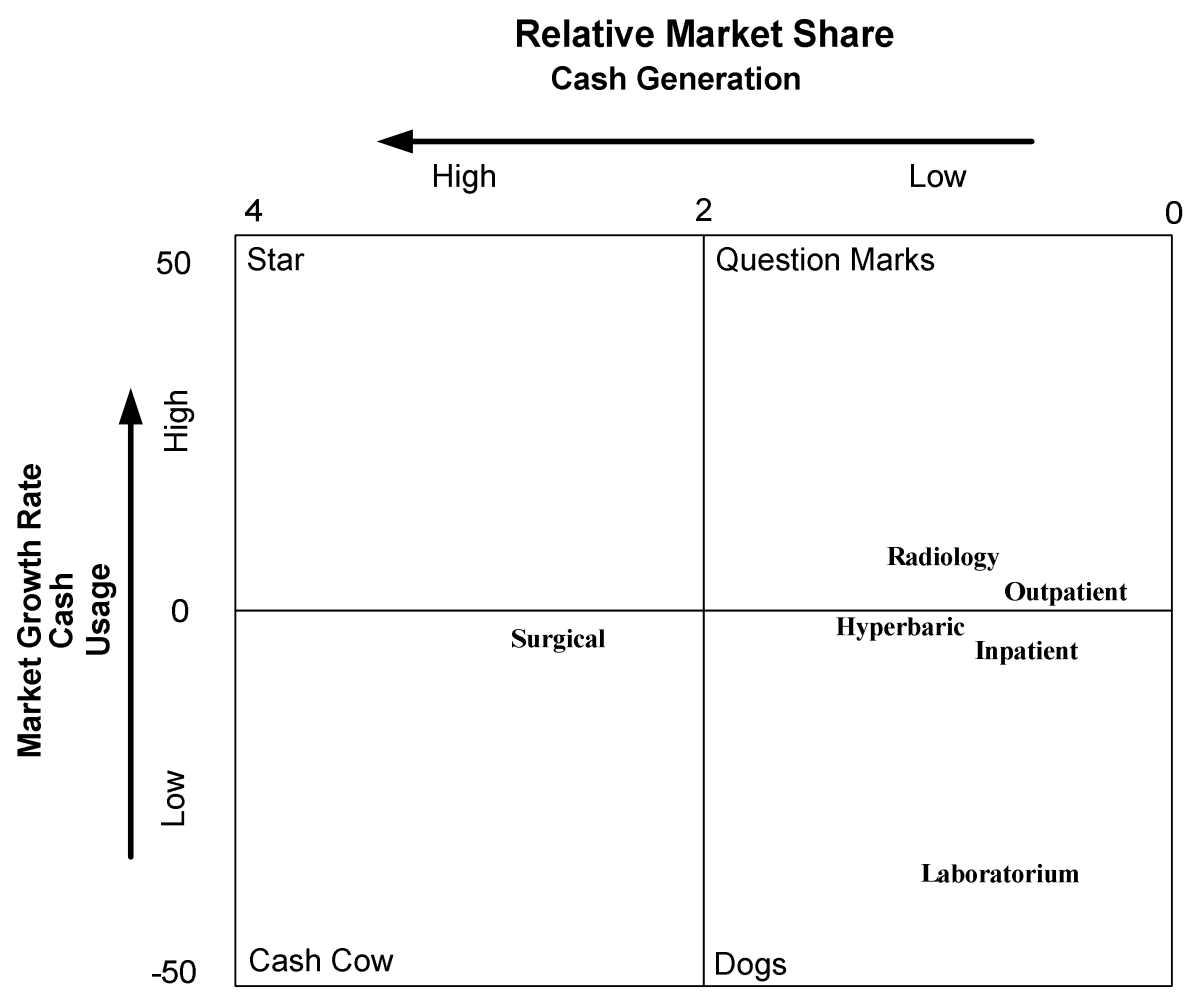

Fig. 1. BCG Matrix 


\subsection{Internal Business Environment Analysis}

This analysis is used to identify the strengths and weaknesses of an organization. Value Chain, SWOT, and Critical Success Factors (CSF) are all the tools that were used to analyze the situation.

\section{Value Chain}

Value Chain model by Martinelly, Riane, and Guinet [13] is specifically developed for hospital environment. The main activities from the model include Admissions Logistics, Care Services, Discharge Logistics, Marketing and Sales. Other supporting activities include Infrastructure, Human Resource Management, Technological Development, and Procurement. Figure 2 shows the Value Chain model for the naval hospital.

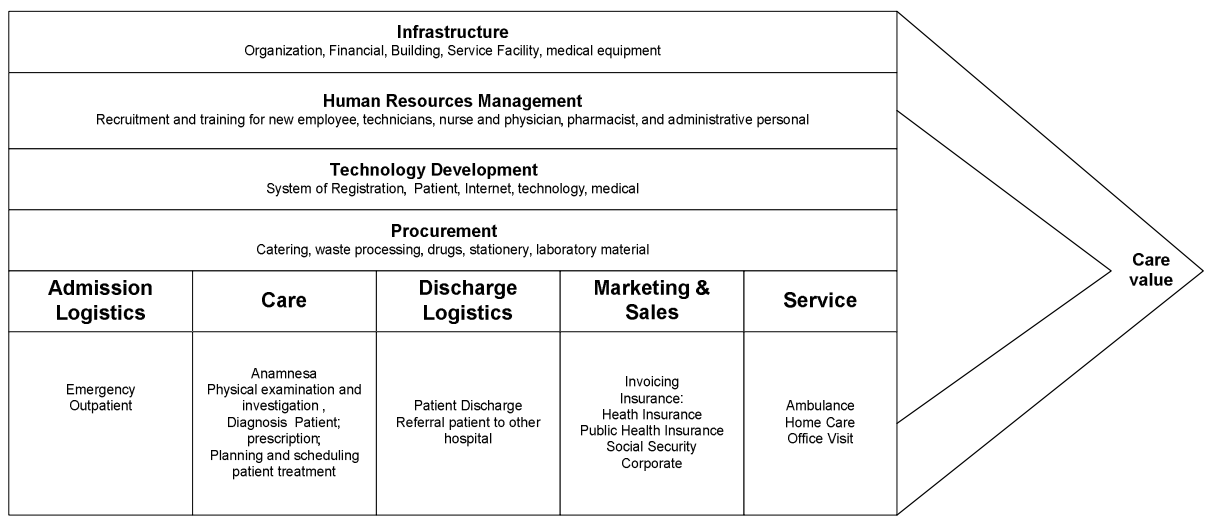

Fig. 2. Value Chain Model

\section{SWOT Analysis}

SWOT analysis is a tool that can be used to identify the internal and external strengths and weaknesses of a company [14]. SWOT analysis can help the organization in developing a strategy as well as in preparing for a better future [15]. In an industry, SWOT analysis is used to provide the leader/management team with basic information regarding the company's development policies for future growth [16]. Figure 3 shows the result of SWOT analysis.

\section{Critical Success Factors (CFS)}

Critical Success Factors are critical activities needed to obtain a successful (or failing) company. CSF can help provide a better understanding on the needs of customers, as well as better construct the marketing division's strategy, management, and evaluation [17]. The result of the CSF analysis for the naval hospital is shown in Table 1. 


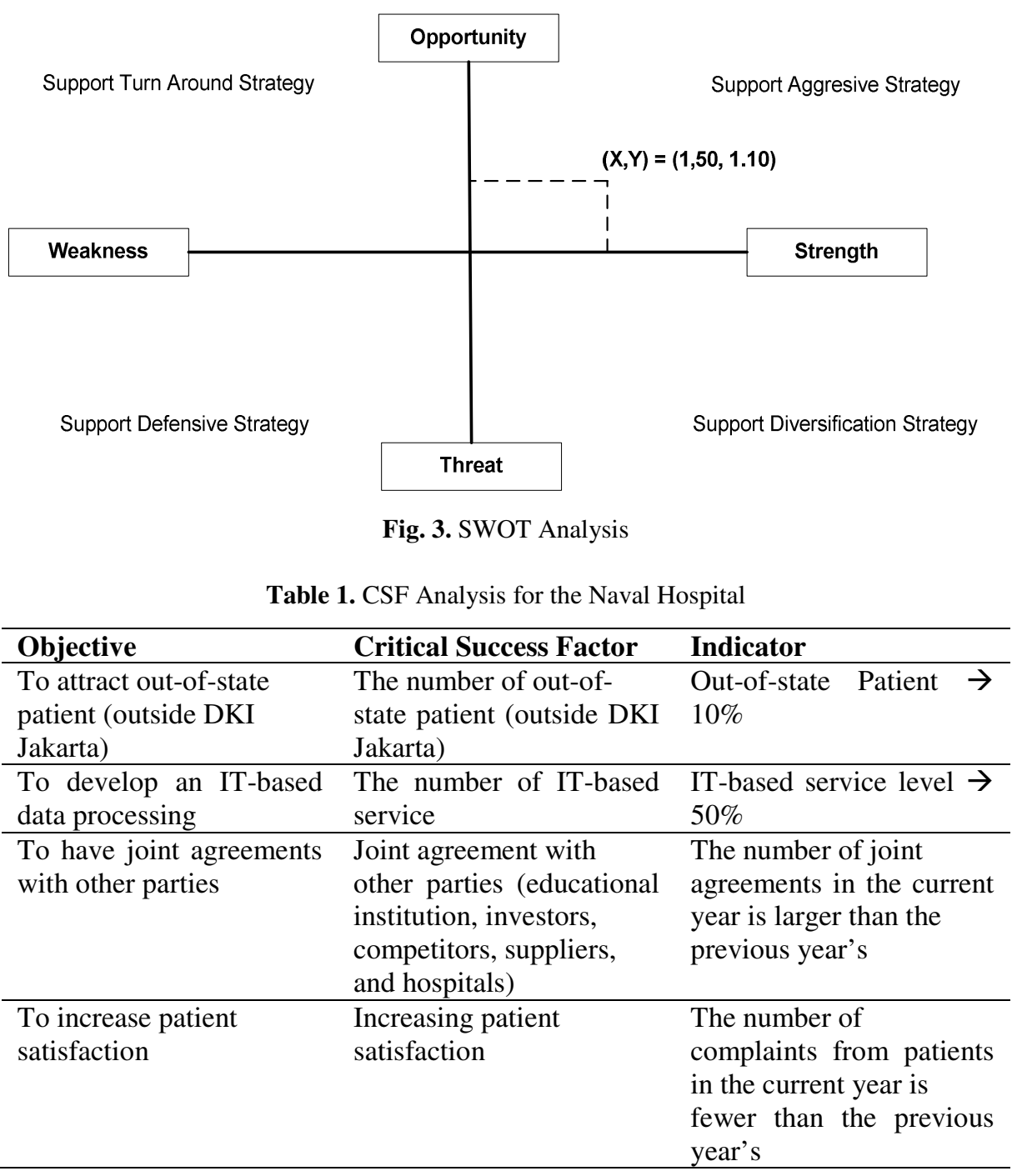

\subsection{External IT/IS Environment Analysis}

Progress made in the Hospital Information System (HIS), such as Radiology Information System (RIS) and Laboratory Information System (LIS) significantly impacts the hospital's operation. LIS creates a dynamic link among the laboratory analyzers, medical technologists, and clinical providers. LIS, combined with an automated process, has the potential to increase work efficiency and quality, reduce human errors, and lab sample tracking (a task often hampered by human errors) [18]. Additionally, developments in telemedicice and SMS gateway can also increase the competitive field within the healthcare industry. For the current available services, the naval hospital lacks two aspects, the Radiology Information System (RIS) and 
Laboratory Information System (LIS). On the other hand, both the naval hospital and its competitors lack the version of HIS that integrates telemedicine, SMS gateway, and medical tourism. Table 2 below lists a comparison between the naval hospital and its competitors in terms of their service applications as well as recommended services that should be developed in order to improve treatment quality.

Table 2. Service Applications Comparison

\begin{tabular}{|c|c|c|c|c|}
\hline \multirow[b]{2}{*}{ Application } & \multirow{2}{*}{$\begin{array}{c}\text { PK St. } \\
\text { Carolus } \\
\text { Hospital }\end{array}$} & \multirow{2}{*}{$\begin{array}{l}\text { PELNI } \\
\text { Hospital }\end{array}$} & \multicolumn{2}{|c|}{ Naval Hospital } \\
\hline & & & Current & $\begin{array}{c}\text { Under } \\
\text { Development }\end{array}$ \\
\hline \multicolumn{5}{|l|}{ HIS } \\
\hline - Stand Alone & $\checkmark$ & $\checkmark$ & $\checkmark$ & $\checkmark$ \\
\hline - Integrated & $\bar{X}$ & $\mathrm{X}$ & $\mathrm{X}$ & $\checkmark$ \\
\hline RIS & $\mathrm{X}$ & $\checkmark$ & $\mathrm{X}$ & $\checkmark$ \\
\hline LIS & $\checkmark$ & $\checkmark$ & $\mathrm{X}$ & $\checkmark$ \\
\hline Telemedicine Service & $X$ & $\mathrm{X}$ & $X$ & $\checkmark$ \\
\hline SMS Gateway Service & $\mathrm{X}$ & $\mathrm{X}$ & $\mathrm{X}$ & $\checkmark$ \\
\hline Medical Tourism & $\mathrm{X}$ & $\mathrm{X}$ & $\mathrm{X}$ & $\checkmark$ \\
\hline
\end{tabular}

The development of Mobile Clinical Assistant (MCA) C5 from the previous version also tremendously impacts the hospital's operations. The development of MCA C5 was propelled by an increase in access patients graphics, especially at the point of care, an increase in clinic's documentation, patient care, and to improve the satisfaction of service providers [19].

\subsection{Internal IT/IS Environment Analysis}

The current hospital applications does not cover many hospital operations; it only comprises of outpatient, inpatient, and emergency patient registrations. Additionally, the hardware that the hospital owns is rarely upgraded. The Information System Management (IMS) that is currently utilized is developed with Microsoft Visual Studio .NET 2005 and SQL Server 2005. The architecture is a Web-based and ClientServer combination. All the modules use a Web-based architecture, except for the pharmacy and finance modules, which use the Client-Server architecture. The naval hospital application portfolio can be seen in Table 3 .

HIS development is aligned with the business strategy to improve services and data processing. Its development also begins with the development of an integrated hospital application that is then followed by the online module. The newly designed modules consist of Patients Master Index module (contains detailed information o the patients), Appointments module (assists patients in appointment set-ups with the hospital), Queue Management module (links the data between receptionists and schedulers), Registration module (records patient registrations manually, online, or through SMS), Outpatient module (manages outpatient transaction), Inpatient and Labor module (manages inpatient transaction), Medical Record Tracking module 
(records and tracks patient medical records), Surgical module (manages surgical patients), Emergency module (manages emergency medical records), Pharmacy module (records and manages prescriptions), Billing module (tracks all billing and payments from patients and/or their affiliated third-party entities), and Logistic module (tracks logistical data).

Table 3. The Naval Hospital Applications Portfolio

\begin{tabular}{|l|l|}
\hline Strategic & High Potential \\
\hline & 1. HIS \\
& $2 . \quad$ RIS \\
& 3. LIS \\
& $4 . \quad$ Telemedicne \\
& $5 . \quad$ SMS gateway \\
& $6 . \quad$ Medical tourism \\
\hline Key Operational & $7 . \quad$ Home care, hospice \\
\hline Registration Information Systems: & Support \\
1. In-patient Application & \\
2. Out-patient Application & \\
3. ER Application & \\
\hline
\end{tabular}

Following the HIS, Radiology Information System (RIS) is developed to meet radiology's needs for consistency in the database that manages modality, material and medical equipment, and data delivery. RIS is a repository for reports and patient data, as well as electronic records for patient data that could help facilitate appointments, track patient information, and provide online reports on diagnostic results [20].

LIS helps screen more people by increasing the capacity of a health promotion center, and brings in more revenue to the center [21]. The LIS, combined with a Clinical Information System such as Computerized Physician Order Entry and Electronical Medical Record, can support improvements in health care services [22].

The next two developments are telemedicine and SMS gateway. Telemedicine is a medical application in which information is transferred through an interactive audio and visual media. Telemedicine aims to deliver medical consultations and examinations to remote area, thereby reducing the patient's need to travel [23]. Telemedicine could potentially overcome geographical barriers, improve access to patients, facilitate collaboration between health care providers in patient treatment, leading to reduction in patient mortality [24]. This technology is also useful for setting primary and specialty care targets in the public health care system, facilitating electronic communication within the specialty care's referral system, assisting hospitals with a primary care focus in remote areas, and improving cooperation between specialists and the rest of the medical staff [25].

Through the use of video conferencing, patients are better prepared at counseling and expressing their ailments, which would lead to improvments in patients satisfaction levels [26]. Telemedicine could also improve the patients' well-being, independence, self management, medical knowledge, and their overall health. 
A module of Virtual Communities for Healthcare can also be used as a virtual selfhelp guide by the patients [27].

Short Message Service (SMS) gateway is a platform that provides a mechanism to deliver and receive SMS from mobile devices as another way to improve services. It can also be used by the organization to monitor, control, and manage the organization's assets [28]. In a service industry, SMS gateway has been used to increase customer satisfaction e.g. its usage in the hospitality industry for hotel reservations [29]. Additionally, the SMS gateway can also be used to distribute information and to ensure that the customers make a wilfull complaints and able to be contacted again when needed [30].

The high cost of treatments in the United States, Europe, Australia, and other developed countries calls for an increasing demand for a more affordable service. That demand can be answered by the expansion of medical tourism, which is a sector of the healthcare service with a more affordable price [31]. This can be done if the system is supported by an international standard for hospital management. Hospital website development is one IT/IS strategy that can be implemented to support medical tourism in order to recruit patients worldwide as well as provide prospective patients with hospital information, such as service rates and available facilities.

The next development is a collaborative information system that aims to store all data from external parties. This module require the collaboration of drug suppliers, competitors, referral hospitals, and medical schools.

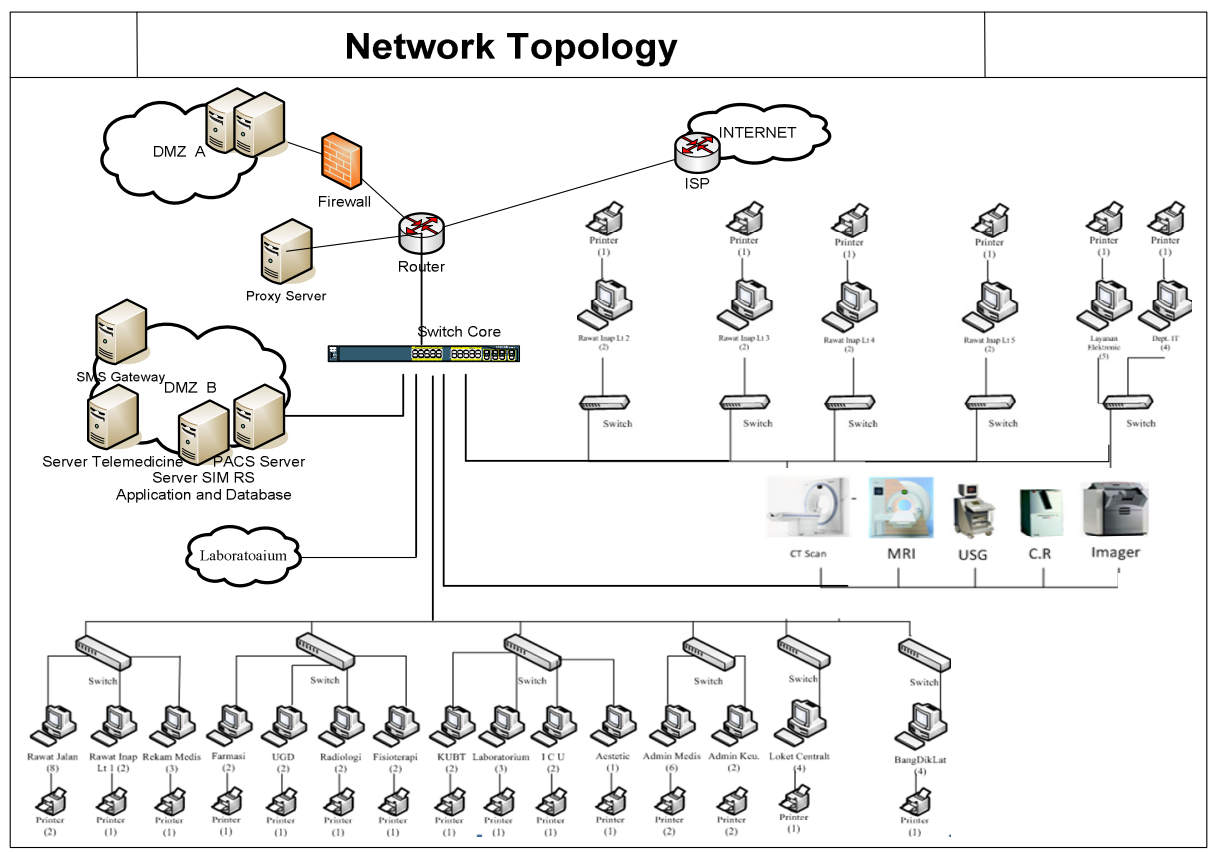

Fig. 4. Overall Strategy IT/IS Network Infrastructure 
The last development is an IS patient service that consists of office visits, home care, hospice comfort care, and taxi. Office visit is a patient session with physicians at the doctor's office but not necessarily at the hospital. An appointment module is needed to support this effort. It is a strategy that is developed as a follow-up treatment for posttreatment ambulatory patients. Home care service is provided by the hospital for patients who feel uncomfortable being treated at the hospital. This service could lead to quality enhancement, error reduction, and patient satisfaction improvement [32]. A module needed for this effort is a registration module that can be integrated with the registration module from the HIS. A hospice service is for patients who can no longer be treated and is given comfort care for the "final call". This service can also be integrated with the HIS especially with the registration, billing, and payment modules.

Figure 4 shows the overall network architecture for the proposed IT/IS strategic planning that includes HIS, RIS, LIS, Telemedicine supported, SMS gateway, medical tourism, as well as all other non-medical services.

\section{Conclusion}

The development of information system strategy provided several added values for the naval hospital's competitive edge. Furthermore, it also redesigned the hospital's applications portfolio. The result of this new strategy offered new products and services such as telemedicine, medical short message service gateway, medical tourism, and home care.

\section{References}

1. Henderson, J.C., Sifonis, J.G.: The Value of Strategic IS Planning: Understanding, Consistency, Validity, and IS Markets. MIS Quarterly 12, 186-200 (1988)

2. Adams, J.: Successful Strategic Planning: Creating Clarity. Journal of Healthcare Information Management 19, 3 (2005)

3. Hartog, C., Herbert, M.: Opinion Survey of MIS mManagers: Key Issues. MIS Quarterly 12,4 (1985)

4. Porter, M.E.: Competitive Advantage: Creating and Sustaining Superior Performance. Free Press, New York (1985)

5. Earl, M.J.: Management Strategies for Information Systems Planning. Prentice Hall, Englewood Cliffs (1989)

6. Wagnera, S.M., Johnson, J.L.: Configuring and Managing Strategic Supplier Portfolios. Industrial Marketing Management 33, 717-730 (2004)

7. Davis, A., Olson, E.M.: Critical Competitive Strategy Issues Every Entrepreneur should Consider before Going into Business. Business Horizons 51, 211-221 (2008)

8. Ward, J., Peppard, J.: Strategic Planning for Information System, 2nd edn. John Wiley \& Sons (2002)

9. Ha, H.: E-Government in Singapore A SWOT and PEST Analysis. Asia-Pacific Social Science Review 6, 103-130 (2006)

10. Ayo, C.K., Adebiyi, A.A., Tolulope, F.I., Ekong, U.O.: A Framework for e-Commerce Implementation: Nigeria a Case Study. Journal of Internet Banking and Commerce 13, 112 (2008) 
11. Armstrong, J.S., Brodie, R.J.: Effects of Portfolio Planning Methods on Decision Making: Experimental Results. International Journal of Research in Marketing 11, 73-84 (1994)

12. Santosa, E., Ling, J.T., Djohanputro, B.: Penerapan Analisis Portofolio untuk Pengambilan Keputusan bagi Pemerintah Provinsi DKI Jakarta pada Perusahaan Patungan. Journal of Management and Business Review 7, 1-12 (2010)

13. Martinelly, D.C., Riane, F., Guinet, A.: A Porter-SCOR Modeling Approach for the Hospital Supply Chain. International Journal of Logistics Systems and Management 5, 436456 (2009)

14. Pesonen, M., Kurttila, M., Kangas, J., Kajanus, M., Heinonen, P.: Assessing the Priorities using a SWOT among Resource Management Strategies at the Finnish Forest and Park Service. Forest Science 47, 534-541 (2001)

15. Chan, X.: A SWOT Study of the Development Strategy of Haier Group as One of the Most Successful Chinese Enterprises. International Journal of Business and Social Science 2, 147-153 (2011)

16. Narayan, P.K.: Fiji's Tourism Industry: A SWOT Analysis. The Journal of Tourism Studies 11, 15-24 (2000)

17. Sahney, S.: Critical Success Factors in Online Retail - An Application of Quality Function Deployment and Interpretive Structural Modeling. International Journal of Business and Information 3, 144-163 (2008)

18. Voegele, C., Tavtigian, S.V., de Silva, D., Cuber, A.S., Thomas, Calvez-Kelm, F.L.: A Laboratory Information Management System (LIMS) for a High Throughput Genetic Platform Aimed at Candidate Gene Mutation Screening. Bioinformatic Applications Note 23, 2504-2506 (2007)

19. Baltimore, Maryland. Clinician Usability Study: Workflow and Clinician Satis-faction Improvement for Physician CPOE and Nursing eMAR using the Motion C5 with Cerner. UMMS White Paper - C5 Mobile Clinical Assistant (2008)

20. Nor, R.M.: Medical Imaging Trends and Implementation: Issues and Challenges for Developing Countries. Journal of Health Informatics in Developing Countries 5, 89-98 (2011)

21. Chae, Y.M., Lim, H.S., Lee, J.H., Bae, M.Y., Kim, G.H.: The Development of an Intelligent Laboratory Information System for a Community Health Promotion Centre. Asia Pac. J. Public Health 14, 64-68 (2002)

22. Harrison, J.P., McDowell, G.M.: The Role of Laboratory Information Systems in Healthcare Quality Improvement. International Journal of Health Care Quality Assurance 21, 679-691 (2008)

23. Fabbrocini, G., De Vita, V., Pastore, F., D’Arco, V., Mazzella, C., Annunziata, M.C., Cacciapuoti, S., Mauriello, M.C., Monfrecola, A.: Teledermatology: From Prevention to Diagnosis of Nonmelanoma and Melanoma Skin Cancer. International Journal of Telemedicine and Applications, 1-5 (2011)

24. Selinger, S.J., Bates, J., Araki, Y., Lear, S.A.: Internet-Based Support for Cardiovascular Disease Management. International Journal of Telemedicine and Applications, 1-9 (2011)

25. Coelho, K.R.: Identifying Telemedicine Services to Improve Access to Specialty Care for the Underserved in the San Francisco Safety Net. International Journal of Telemedicine and Applications, 1-14 (2011)

26. Dansky, K.H., Bowles, K.H., Palmer, L.: How Telehomecare Affects Patients. Caring 18, 10-14 (1999)

27. Chorbev, I., Sotirovska, M., Mihajlov, D.: Virtual Communities for Diabetes Chronic Disease Healthcare. International Journal of Telemedicine and Applications, 1-7 (2011) 
28. Hakim, A.R., Bramanto, A., Syahri, R.: Aplikasi Monitoring Suhu Ruangan Berbasis Komputer dan SMS Gateway. Jurnal Informatika Mulawarman 5, 32-38 (2010)

29. Rahayu, S., Zulmansyah, N.: Perancangan Aplikasi Reservasi Kamar untuk Pelanggan Tetap dengan Menggunakan SMS Gateway. SINAPTIKA 3 (2012)

30. Utomo, H.T., Samopa, F., Setiawan, B.: Pengembangan Sistem Pengaduan Kon-sumen Terkait Bisnis Online Berbasis Facebook Open Graph Protocol dan SMS Gateway. Jurnal Teknik ITS 1, 362-367 (2012)

31. Jones, C.A., Keith, L.G.: Medical Tourism and Reproductive Outsoursing: The Dawning of a New Paradigm for Healthcare. International J. of Fertility and Women's Medicine 51, 251-255 (2006)

32. Thomas, C.R.: The Medical Home: Growing Evidence to Support a New Approach to Primary Care. J. of American Board of Family Medicine 21, 427-440 (2008) 